\title{
PERLAKUAN PENCATATAN PADA KONVERSI MUSYARAKAH GUNA MENANGGULANGI PEMBIAYAAN BERMASALAH
}

\author{
Aji Prasetyo \\ Universitas PGRI Adi Buwana Surabaya \\ Email: aji.estiga@gmail.com
}

\begin{abstract}
This research is the result of qualitative research which aims to analyze the conversion of musyarakah contract in reducing the risk of murabaha problem and accountancy treatment on akad conversion in murabahah financing problem in syariah bank. Qualitative method used in this study with the type of case study research. The research data was collected by interviewing the informant, one of the heads of the finance division. The results showed that first, one of the efforts to overcome murabaha problem is restructuring in the form of conversion to musyarakah financing. Secondly, conversion to musyarakah financing means closing the book all relating to murabahah's previous financing. Then, the remaining obligations that he can not afford are converted into musharaka financing. The financing made for business activities with the banks and customers equally provide capital. In this case, the capital of the bank is the nominal residual liability of the customer and the capital of the customer is the object of financing.
\end{abstract}

Keywords: Problematic financing, conversion, accounting

Dalam praktik perbankan maupun praktik-praktik bisnis, sudah menjadi kebiasaan bahwasanya dalam memberikan fasilitas kepada para pengguna jasa atau nasabah, hubungan hukum antara bank dan para nasabah dituangkan dalam bentuk perjanjian tertulis. Begitu juga dalam perjanjian pembiayaan serta bentuk-bentuk kemitraan yang lainnya. Pengertian dari perjanjian pembiayaan ini adalah suatu perjanjian yang menimbulkan hubungan hukum antara bank dengan nasabah dalam hal bank berjanji untuk memberikan fasilitas kepada nasabah dan pihak nasabah berwenang untuk mengelola pembiayaan tersebut.

Sebagaimana perbankan konvensional, bank syariah juga berfungsi sebagai lembaga intermediasi, yaitu menghimpun dana dari masyarakat yang berkelebihan dan menyalurkan dana-dana tesebut kepada orang yang membutuhkannya dalam bentuk pembiayaan. Sektor pembiayaan merupakan sumber utama pendapatan yang diperoleh bank, sebab penggunaan dana yang diterima oleh bank, sebanyak 70-80\% dialokasikan pada usaha pembiayaan (Harja, 2013). Oleh karena itu di satu sisi, sektor pembiayaan mampu mendatangkan keuntungan yang besar, akan tetapi di sisi yang lain sektor pembiayaan juga memiliki risiko yang besar. Sehingga apabila sampai terjadi pembiayaan bermasalah, maka secara tidak langsung akan mempengaruhi kesehatan suatu perbankan.
Penyebab utama terjadinya risiko pembiayaan ditengarai oleh bank yang mudah menyalurkan pembiayaan untuk memaksimalkan porsi likuiditas, sehingga terjadi penilaian pembiayaan yang kurang cermat kemudian menimbulkan risiko pembiayaan tersebut bermasalah (Arifin, 2006: 225). Dikatakan suatu pembiayaan itu berisiko bermasalah apabila pembiayaannya macet dan harus segera ditangani oleh bank. Oleh karena itu, pihak bank harus memiliki prinsip kehati-hatian diantaranya melakukan tindakan preventif terhadap nasabah (Kasmir, 2007: 29).

Data menunjukkan bahwa pada akhir tahun 2016, rasio NPF bank syariah mencapai $4,3 \%$, sementara bank konvensional hanya sebesar 2\% (OJK, 2014). Dengan rasio NPF yang lebih besar dibanding dengan perbankan konvensional tersebut, menjadikan ironi sebab pada dasarnya perbankan syariah yang berlandaskan prinsip bagi hasil semestinya memiliki risiko gagal bayar atau pembiayaan bermasalah yang lebih kecil daripada dengan sistem bunga. Oleh karena itu, untuk meminimalisasi risiko pembiayaan bermasalah diperlukan prinsip kehati-hatian dalam menyalurkan dana pada masyarakat berdasarkan Pasal 36 UndangUndang Perbankan Syariah (Mujiyono, 2015). Tujuan diberlakukannya prinsip kehati-hatian tidak lain agar bank-bank selalu dalam keadaan sehat, sehingga selalu dalam keadaan likuid, solvent dan menguntungkan 
(profitable). Dengan diberlakukannya prinsip kehatihatian itu diharapkan kadar kepercayaan masyarakat terhadap perbakan selalu tinggi sehingga masyarakat bersedia dan tidak ragu-ragu menyimpan dananya di bank (Atikah, 2015).

Faktanya, walaupun bank telah menerapkan Pasal 23 ayat (1) Undang-Undang Perbankan Syariah, akan tetapi masih juga ditemui masalah dalam pembiayaan tersebut pasca terjadinya akad, mulai dari penurunan kemampuan dalam pembayaran, sampai yang terfatal adalah pembiayaan macet, yang dapat mengancam kesehatan bank. Sehingga hal tersebut harus mendapatkan perhatian yang serius dari pihak yang terkait.

Pada dasarnya, ketika ada suatu pembiayaan yang bermasalah maka pihak bank harus melakukan penyelamatan terhadap pembiayaan itu sebagaimana Peraturan Bank Indonesia Nomor 13/9/PBI/2011 Tentang Restrukturisasi Pembiayaan Bagi Bank Syariah dan Unit Usaha Syariah. Peraturan Bank Indonesia ini memberikan beberapa solusi atas pembiayaan bermasalah yang dialami oleh lembaga keuangan syariah. Menariknya, lembaga keuangan syariah ketika menghadapi persoalan pembiayaan bermasalah lebih memilih mengkonversi akad dari pada alternatif yang lain. Seperti mengkonversi akad murabahah yang juga telah diatur melalui Fatwa DSN-MUI. Ketika terjadi pembiayaan murabahah macet, langkah terakhir saat restrukturisasi adalah mengkonversi pembiayaan murabahah tersebut menjadi pembiayaan musyarakah.

Konversi pembiayaan murabahah ke skema musyarakah berarti berbeda pula bentuk perlakuan akuntansinya. Perlakuan akuntansi pada skema musyarakah nantinya dapat menunjukkan minimalisasi risiko pembiayaan murabahah pada skema sebelumnya. Penelitian ini bertujuan untuk mendeskripsikan penanganan pembiayaan murabahah bermasalah melalui konversi ke pembiayaan musyarakah dan perlakuan akuntansinya.

\section{Pembiayaan Bank Syariah}

Bank syariah merupakan lembaga perantara keuangan bagi pihak yang kelebihan dana dengan pihak yang kekurangan dana untuk kegiatan usaha dan kegiatan lainnya sesuai dengan hukum Islam. Bank syariah disebut sebagai Islamic Banking atau interest fee banking, yaitu suatu sistem perbankan yang dalam pelaksanaan operasionalnya tidak menggunakan sistem bunga, spekulasi dan ketidakpastian atau ketidakjelasan (Ali, 2010: 1-2).
Posisinya sebagai lembaga keuangan, bank syariah memiliki tiga fungsi utama yaitu menghimpun dana dari masyarakat dalam bentuk titipan dan investasi, menyalurkan dana kepada masyarakat yang membutuhkan dalam bentuk pembiayaan dan memberikan pelayanan dalam bentuk jasa perbankan syariah. Penghimpunan dana dari masyarakat dalam bentuk titipan biasanya menggunakan akad wadi'ah dan dalam bentuk investasi menggunakan akad mudarabah. Fungsi bank syariah yang kedua yaitu menyalurkan dana kepada masyarakat dalam bentuk pembiayaan dapat menggunakan akad jual beli (murabahah, salam dan istithna'), akad sewa (ijarah) dan akad kemitraan/kerja sama usaha (musharakah dan mudarabah). Adapun fungsi yang ketiga bank syariah adalah memberikan pelayanan jasa perbankan kepada masyarakat berupa pengiriman uang (transfer), penagihan surat berharga, dan lain-lain (Ismail, 2011:39-42).

Fungsi bank syariah yang juga merupakan kegiatan yang dilakukannya selain menerima dana dari masyarakat, juga menyalurkan dana yang dinamakan pembiayaan. Pembiayaan atau financing dapat diartikan sebagai pemberian dana yang diberikan oleh suatu pihak kepada pihak lain untuk mendukung investasi yang telah direncanakan, baik dilakukan sendiri maupun lembaga. Kaitannya dengan pembiayaan pada perbankan Islam, istilah teknisnya disebut aktiva produktif. Aktiva produktif adalah penanaman dana bank syariah baik dalam rupiah maupun valuta asing dalam bentuk pembiayaan, piutang, qard dan sertifikat wadi'ah (Rivai dan Arifin, 2010: 681).

\section{Prinsip Kehati-hatian Bank Syariah}

Prinsip kehati-hatian perbankan atau disebut juga prudential banking, diambil dari kata bahasa inggris "prudence" yang artinya bijaksana atau berhati-hati (Gandapraja, 2004: 21). Istilah "prudent" sangat terkait dengan pengawasan dan manajemen bank. Dalam pengertian lain, prudential banking didefinisikan dengan suatu asas yang menyatakan bahwa bank dalam menjalankan fungsi dan kegiatan usahanya menempuh cara-cara yang tidak merugikan bank dan kepentingan nasabah dengan tujuan agar bank selalu dalam keadaan sehat (Ibrahim, 2004: 88).

Bentuk prinsip kehati-hatian bank diantaranya adalah prinsip mengenal nasabah (know your customer principles), yaitu membuat suatu kebijakan dan prosedur penerapan Prinsip Mengenal Nasabah. Prinsip ini terdiri dari kebijakan dan prosedur penerimaan dan identifikasi nasabah, pemantauan rekening 
nasabah, pemantauan transaksi nasabah, serta kebijakan dan prosedur manajemen risiko. Penerapan kebijakan dan prosedur tersebut bertujuan agar bank dapat mengenali profil nasabah, maupun karakteristik setiap transaksi nasabah sehingga pada gilirannya bank dapat mengidentifikasi Transaksi Keuangan Mencurigakan (suspicious transactions) dan selanjutnya melaporkan pada PPATK (Rivai dan Ismail, 2013: 406).

Prinsip kehati-hatian ini harus dijalankan oleh bank, bukan hanya karena dihubungkan dengan kewajiban agar bank tidak merugikan kepentingan nasabah yang mempercayakan dananya kepada bank dan masyarakat (melalui penyaluran kredit bank), melainkan juga berkaitan erat dengan upaya penanganan risiko yang melekat pada bank syariah salah satunya adalah risiko pembiayaan bermasalah (Sjedeni, 2013: 175).

\section{Upaya Penanggulangan Pembiayaan Bermasalah}

Apabila bank syariah mengalami pembiayaan yang bermasalah/macet, maka harus dilakukan upaya untuk menangani pembiayaan bermasalah tersebut, agar dana yang telah disalurkan oleh bank syariah dapat diterima kembali. Dikategorikan sebagai pembiayaan bermasalah (non Performing financing/ NPF) jika kualitas pembiayaan mulai masuk golongan dalam kurang lancar sampai golongan Macet (Bank Indonesia, 2011).

Strategi dalam menangani pembiayaan bermasalah, terdiri dari 2 (dua) pilihan. Pertama, melanjutkan hubungan dengan nasabah. Strategi ini dilakukan apabila nasabah memenuhi beberapa kriteria bahwa nasabah dinilai kooperatif dan masih memiliki prospek usaha, serta melakukan langkah-langkah restrukturisasi (rescheduling, reconditioning atau restructuring).

Strategi kedua dalam menangani pembiayaan bermasalah adalah dengan cara memutuskan hubungan dengan nasabah. Hal ini dilakukan apabila nasabah dinilai tidak kooperatif dan atau sudah tidak memiliki prospek usaha. Maka penyelesaian pembiayaan dilakukan melalui penyerahanan agunan atau litigasi yang berupa eksekusi objek jaminan dan gugatan Perdata. Beberapa upaya penangangan pembiayaan bermasalah oleh bank syariah adalah:

\section{Restrukturisasi Pembiayaan Bermasalah}

Berdasarkan Fatwa DSN No. 46/DSN-MUI/II2005, langkah-langkah restrukturisasi dilakukan dengan tiga cara, yaitu penjadwalan kembali (re- schedulling), persyaratan kembali (reconditioning), dan penataan kembali (restructuring). Penjadwalan kembali (reschedulling) yaitu memperpanjang jatuh tempo pembiayaan. Persyaratan kembali (reconditioning) yaitu menetapkan kembali syarat-syarat pembiayaan. Penataan kembali (restructuring) yaitu dengan konversi piutang murabahah atau piutang istishna sebesar sisa kewajiban nasabah menjadi ijarah muntahiyah bittamlik atau mudharabah atau musyarakah (Fatwa DSN No. 49/DSN-MUI/ II-2005). Namun apabila akad di awal yang digunakan adalah mudharabah atau musyarakah, penataan kembali yang dapat dilakukan adalah dengan cara penambahan dana dari bank kepada nasabah agar kegiatan usaha nasabah dapat berjalan kembali, sesuai dengan syarat dan ketentuan yang berlaku.

\section{Penyelesaian Pembiayaan Bermasalah Melalui Penyerahan Agunan (AYDA)}

Istilah dalam Peraturan Bank Indonesia Nomor 10/PBI/2008 Tentang Restrukturisasi Pembiayaan Bagi Bank Syariah dan Unit Usaha Syariah adalah Agunan yang Diambil Alih (AYDA), yaitu aktiva yang diperoleh Bank, baik melalui pelelangan maupun diluar pelelangan berdasarkan penyerahan secara sukarela oleh pemilik agunan atau berdasarkan kuasa untuk menjual diluar lelang dari pemilik agunan dalam hal nasabah tidak memenuhi kewajibannya kepada Bank. Dilakukannya proses penyelesaian pembiayaan melalui penjualan barang yang menjadi agunan pembiayaan/ aset nasabah yang lain adalah agar hasil penjualannya dapat dipergunakan sebagai pelunasan atau pembayaran kewajibannya pada bank syariah.

Penjualan agunan dapat dilakukan kepada pihak lain (yang tidak terkait hubungan hukum dengan bank syariah), baik dilakukan sendiri oleh nasabah atau pemilik agunan, ataupun dengan bantuan bank syariah dalam kapasitasnya sebagai perantara transaksi penjualan barang. Penjualan agunan juga dapat dilakukan kepada Bank Syariah atau dengan kata lain dibeli sendiri oleh bank Syariah melalui pejabat/karyawan yang ditunjuk untuk itu ataupun langsung oleh bank syariah, umumnya dikenal dengan istilah Offset Agunan sebagaimana diatur pada Pasal 40 UU No. $21 / 2008$.

\section{Penyelesaian Melalui Badan Arbitrase Syariah Nasional}

Pada Pasal 20 ayat (2) Peraturan Bank Indonesia Nomor 7/46/PBI/ 2005 tentang Akad Penghimpunan dan Penyaluran Dana bagi Bank yang Melaksana- 
kan Kegiatan Usaha Kesepakatan, penyelesaian lebih lanjutnya dapat dilakukan melalui alternatif penyelesaian sengketa atau Badan Arbitrase Syariah.” Pasal 4 ayat (3) Peraturan Bank Indonesia Nomor 9/19/ PBI/2007 tentang Pelaksanaan Prinsip Syariah dalam Kegiatan Penghimpunan Dana dan Penyaluran Dana serta Pelayanan Jasa Bank Syariah pun menyatakan penyelesaian sengketa perbankan syariah melalui mekanisme arbitrase syariah baru dapat dilakukan jika penyelesaian sengketa melalui mediasi, termasuk mediasi perbankan tidak mencapai kesepakatan. Jadi, mekanisme arbitrase syariah baru dapat dilakukan jika penyelesaian sengketa perbankan syariah melalui musyawarah dan mediasi tidak mencapai kata sepakat.

Keputusan yang dibuat oleh Basyarnas mempunyai kekuatan mengikat. Putusan arbitrase bersifat final and binding, yang berarti mempunyai kekuatan hukum tetap dan mengikat, tidak ada banding, kasasi maupun peninjauan kembali. Oleh karena itu, para pihak harus melaksanakan putusan Basyarnas tersebut secara sukarela.

\section{Penyelesaian Melalui Litigasi}

Bank akan menempuh penyelesaian lewat litigasi apabila nasabah tidak beritkad baik, yaitu tidak menunjukkan kemauan untuk memenuhi kewajibannya sedangkan nasabah sebenarnya masih mempunyai harta kekayaan yang tidak dikuasai oleh bank atau sengaja menyembunyikan atau mempunyai sumbersumber lain untuk menyelesaikan kredit macetnya. Pasal 49 Undang-Undang Nomor 3 Tahun 2006 tentang Peradilan Agama (UU No. 3/2006) menyatakan kewenangan penyelesaian sengketa perbankan syariah juga menjadi kompetensi absolut dari Pengadilan Agama dalam lingkungan peradilan agama, bahkan meliputi pula bidang ekonomi syariah lainnya di luar bidang perbankan syariah. Berdasarkan penjelasan Pasal 49 UU No. 3/2006 tersebut, maka seluruh nasabah lembaga keuangan dan lembaga pembiayaan syariah, atau bank konvensional yang membuka unit usaha syariah dengan sendirinya terikat dengan ketentuan ekonomi syariah, baik dalam pelaksanaan akad maupun dalam penyelesaian perselisihan (Dewi, dkk, 2005: 31).

\section{METODE PENELITIAN}

Penelitian ini merupakan jenis penelitian deskripsi kualitatif yang memfokuskan pada permasalahan penanganan pembiayaan murabahah bermasalah (macet). Sumber-sumber data didapat dari beberapa sumber primer dan sekunder. Sumber data primer adalah sumber informasi dari subjek penelitian dengan penggalian data menggunakan alat pengukuran atau pengambilan secara langsung (wawancara) (Azwar, 2007: 91). Perolehan sumber data primer dalam penelitian ini dilakukan dengan teknik purposive sampling. Purposive sampling yaitu teknik pengambilan sampel sumber data dengan pertimbangan tertentu. Pertimbangan ini ditentukan bahwa subjek tersebut dianggap paling tahu tentang data yang peneliti harapkan, atau dia sebagai penguasa data sehingga akan memudahkan peneliti menjelajahi objek yang diteliti (Sugiyono, 2013: 300). Sumber data primer dalam penelitian ini ditempati oleh divisi yang memiliki otoritas terhadap kebijakan pembiayaan dalam hal ini adalah Bapak Juniar Endrawanto.

Sumber data sekunder adalah sumber data penelitian yang diperoleh secara tidak langsung (Bungin, 143) atau data kepustakaan yang ada hubungannya dengan audit internal perusahaan dan risiko pembiayaan. Sumber data ini dapat diperoleh dari buku-buku, jurnal maupun literatur lain.

Penganalisisan data yang telah terkumpul dilakukan secara analisis deskriptif kualitatif, yaitu analisis yang menghasilkan data deskriptif berupa kata-kata tertulis atau dari penuturan lisan orang-orang dan perilaku yang dapat diamati dengan metode yang telah ditentukan. Tujuan dari metode ini adalah untuk membuat deskripsi atau gambaran mengenai objek penelitian secara sistematis, faktual dan akurat mengenai fakta-fakta, sifat-sifat antar fenomena yang diselidiki (Nazir, 2005: 63)

\section{HASIL DAN PEMBAHASAN}

\section{Penanganan Pembiayaan Murabahah Bermasa- lah Melalui Konversi ke Pembiayaan Musyara- kah}

Sebagaimana disebutkan, bahwa restrukturisasi merupakan langkah penanganan pembiayaan bermasalah. Risiko terjadinya pembiayaan bermasalah yang paling besar pun di pembiayaan murabahah. Sehingga memang perlu ada langkah strategis yang tidak merugikan pihak bank maupun nasabah yang kesulitan dalam melanjutkan angsuran pembiayaannya.

Dalam mengelola perubahan yang disebabkan dari berbagai permasalahan yang timbul maka diperlukan adanya restrukturisasi pada pembiayaan yang bermasalah. Pada kasus pembiayaan murabahah yang bermasalah, langkah yang dilakukan Bank Muamalat dalam tahap restrukturisasi adalah dengan mengkon- 
versi ke pembiayaan musyarakah. Hal ini dilakukan sesuai dengan dasar hukumnya.

Pembiayaan murabahah yang diterapkan bank syariah biasanya banyak digunakan dalam pembiayaan jangka waktu pendek (short- term financing), dan penandatangan akad jual beli atau murabahah dilakukan pada hari dan tempat yang sama, hanya saja akad jual beli bank dengan pemasok telah terlaksana sebelum akad murabahah antara bank dan nasabah ditandatangani. Pembiayaan jangka pendek dan penandatangan akad jual beli dan murabahah berlangsung pada hari dan tempat yang sama tersebut, akan berpengaruh pada tingkat risiko bank. Namun demikian, kerugian dapat saja terjadi, oleh karena itu restrukturisasi perlu dilakukan. Restrukturisasi pembiayaan murabahah adalah upaya yang dilakukan oleh bank syariah untuk meminimalkan potensi kerugian yang disebabkan oleh pembiayaan murabahah (Zaeni, 2010).

Restrukturisasi pembiayaan dapat dilakukan setelah nasabah mengajukan permohonan tertulis untuk dilakukannya restrukturisasi pembiayaan yang dibuat oleh nasabah sendiri dan usia nasabah tersebut tidak melebihi 65 tahun pada saat jatuh tempoperpanjangan jangka waktu. Restrukturisasi pembiayaan dilakukan denganmembuat akad baru dan maksimal perpanjangan jangka waktu pelunasan angsuran selama 15 tahun. Upaya penyelesaian pembiayaan murabahah bermasalah dilakukan apabila pada tahap penyelamatan pembiayaan murabahah bermasalah tidak berhasil.

Konversi ke pembiayaan musyarakah ini berarti menutup buku (secara akuntansi) semua yang berkaitan dengan pembiayaan murabahah yang sebelumnya (jumlah kewajiban yang mampu dibayar nasabah). Kemudian, sisa kewajiban yang tidak mampu dibayarkannya dikonversi menjadi pembiayaan musyarakah. Artinya, pembiayaan yang dilakukan untuk kegiatan usaha dengan pihak bank dan nasabah sama-sama memberikan modal. Dalam hal ini, modal dari bank adalah nominal sisa kewajiban nasabah dan modal dari nasabah adalah objek pembiayaan (barang yang dibeli saat pembiaayaan murabahah).

\section{Perlakuan Akuntansi Konversi Akad Musyara- kah sebagai Bentuk Penanganan Pembiayaan Murabahah Bermasalah}

Berdasarkan Butir VI angka (1) huruf (c) SEBI No. 10/34/DPBS/2008, Bank syariah dapat melakukan penataan kembali dengan mengkonversi piutang pembiayaan murabahah dengan beberapa cara. Pertama, menghentikan pembiayaan murabahah dengan memperhatikan nilai wajar objek murabahah. Kedua, objek pembiayaan murabahah sebelumnya menjadi dasar untuk pembuatan akad pembiayaan baru. Ketiga, melakukan akad pembiayaan baru dengan mempertimbangkan kondisi nasabah, antara lain golongan nasabah, jenis kegiatan usaha, dan kemampuan (cash flow) nasabah. Keempat, mencantumkan kronologis akad pembiayaan murabahah sebelumnya dalam akad pembiayaan baru (Faisal, 2011).

Praktik akad murabahah yang dikonversi ke akad musyarakah adalan obyek murabahah/jaminan nasabah yang dibeli oleh LKS diakui sebagai aset/ persediaan. Hasil penjualan diakui sebagai pelunasan tagihan murabahah, jika ada sisa maka diakui sebagai bagian modal musyarakah. Perlakuan akuntansi untuk akad baru sesuai dengan PSAK terkait. Konversi akad murabahah diakui sesuai dengan akad baru yang disepakati. Perlakuan akuntansinya dapat digambarkan dalam contoh kasus berikut:

Bapak A mengajukan pembiayaan murabahah untuk membeli mobil sebesar nominal $\mathrm{Rp}$ 150.000.000,- (pokok Rp 120.000.000,- dan margin Rp 30.000.000,-) selama 4 tahun. Pada tahun pertama dan kedua, si A masih mampu membayar kewajibannya. Namun pada tahun ketiga dikategorikan macet karena menunggak selama 4 bulan. Di bulan ke-5 Bapak A mendatangi bank dan menjelaskan alasannya tidak melakukan pembayaran serta berkeinginan untuk melanjutkan pembayaran. Atas kejadian tersebut disepakati piutang murabahah Bapak Adirestrukturisasi dengan dikonversi ke akad musyarakah dengan piutang atas nama Bapak A sebesar Rp 75.000.000,(pokok Rp 60.000.000,- dan margin Rp 15.000.000,-)

\section{Jurnal transaksi :}

1. Bank membeli objek murabahah/jaminan sebesar jumlah sisa piutang murabahah Bapak A yaitu Rp 75.000.000. Objek murabahah yang dibeli diakui sebagai aset musyarakah Jurnal : 
Aji Prasetyo

Mei 2016

$\mathrm{Db} \quad$ Aset Musyarakah

Rp 75.000.000

$\mathrm{Cr} \quad$ Kas / Rek Nasabah

Rp 75.000.000

2. Hasil penjualan objek murabahah / jaminan digunakan oleh nasabah untuk pelunasan hutang murabahah di bank.

Jurnal :

Mei 2016

$\mathrm{Db} \quad$ Kas / Rek Nasabah

Rp 60.000.000

Cr Piutang Murabahah

Rp 60.000.000

Mei 2016

$\mathrm{Db} \quad$ Margin Murabahah yang Ditangguhkan

Rp 15.000.000

$\mathrm{Cr} \quad$ Pendapatan Margin Murabahah

Rp 15.000.000

3. Kemudian objek murabahah/jaminan yang sudah dibeli oleh BMT dapat dikembalikan ke Bapak Adengan skema akad musyarakah.

Bapak A memiliki usaha toko sembako, bank berkontribusi modal dalam bentuk objek murabahah (mobil) senilai Rp 75.000.000 sedang Bapak A juga berkontribusi modal berupa usaha yang sudah berjalan senilai Rp 100.000.000. Nisbah bagi hasil disepakati 70\% untuk Bapak A dan 30\% untuk bank. Jangka waktu akad musyarakah 24 bulan. Bagi hasil dibayarkan setiap bulan beserta pokok.

Jurnal :

Mei $2016 \quad$ Db Pembiayaan Musyarakah

$\mathrm{Cr} \quad$ Aset Musyarakah

$\operatorname{Rp} 75.000 .000$

Selanjutnya mengikuti jurnal musyarakah.

Rp 75.000.000

Bagi bank, tentunya langkah tersebut tetap dapat menguntungkan karena meski dikonversi ke pembiayaan musyarakah, besar pokok kewajiban dan marjin tetap dibebankan kepada nasabah dalam jumlah yang sama. Kemudian, dalam neraca keuangan bank pun sisa kewajiban tidak lagi menjadi hutang atau piutang tak tertagih. Sisa kewajiban pembiayaan si A hanya dipindah ke laporan keuangan pembiayaan musyarakah menggunakan sistem bagi hasil.

Bagi nasabah, meski besarnya kewajiban tetap sama ia tanggung, namun ada sisi baiknya yaitu karena menjadi pembiayaan musyarakah dengan sistem bagi hasil, maka selama 2 tahun selanjutnya ia hanya membayar kewajiban pokoknya saja, adapun besaran nisbah (yang awalnya besarnya marjin) dapat dibayar di akhir masa pembiayaan yang dapat dipertimbangkan kembali bagi hasilnya oleh bank. Kemudian, karena pembiayaannya menjadi musyarakah (pembiayaan untuk modal usaha), maka nasabah akan mendapat pendampingan dari bank syariah dalam menjalankan usahanya agar tidak sampai rugi dan tetap dapat membayar kewajibannya pada bank hingga memperoleh keuntugan.

\section{KESIMPULAN}

Risiko yang sering timbul dan sangat krusial di bank syariah adalah risiko pembiayaan, terutama pem- biayaan murabahah yang banyak diminati. Oleh karena itu, bank syariah harus dapat menerapkan prinsip kehati-hatian dan upaya penanggulangan pembiayaan bermasalahah.

Salah satu upaya penanggulangan pembiayaan bermasalahah pada murabahah adalah restrukturisasi berupa konversi ke pembiayaan musyarakah. Konversi ke pembiayaan musyarakah ini berarti menutup buku (secara akuntansi) semua yang berkaitan dengan pembiayaan murabahah yang sebelumnya (jumlah kewajiban yang mampu dibayar nasabah). Kemudian, sisa kewajiban yang tidak mampu dibayarkannya dikonversi menjadi pembiayaan musyarakah. Artinya, pembiayaan yang dilakukan untuk kegiatan usaha dengan pihak bank dan nasabah sama-sama memberikan modal. Dalam hal ini, modal dari bank adalah nominal sisa kewajiban nasabah dan modal dari nasabah adalah objek pembiayaan (barang yang dibeli saat pembiaayaan murabahah).

\section{DAFTAR PUSTAKA}

Ali, Zainuddin. 2010. Hukum Perbankan Syariah. Jakarta: Sinar Grafika.

Amelia, Tazkya Putri, Gemala Dewi, dan Aad Rusyad Nurdin. 2016. Tinjauan Yuridis Restruturisasi Pembiayaan Murabahah Bermasalah Pada Bank Syariah, Jurnal Fakultas Hukum Universitas Indonesia. 
Arifin, Zainul. 2006. Dasar-dasar Manajemen Bank Syariah. Jakarta: Pustaka Utama.

Atikah, Jumi. 2015. Prinsip Kehati-Hatian Dalam Pencegahan Pembiayaan Bermasalah, Jurnal Al-Tijaroh, Vol. 1 No. 2.

Bank Indonesia, "Peraturan Bank Indonesia Nomor 13/13/ PBI/2011 Tentang Penilaian Kualitas Pembiayaan”, dalam www.bi.go.id (pdf), diakses 10 Januari 2017.

Bank Indonesia, "Undang-Undang Perbankan Syariah Tahun 2008 Tentang Perbankan Syariah", dalam www.bi.go.id (pdf), diakses 10 Januari 2017.

Dewi, Gemala, dkk. 2005. Hukum Perikatan Islam di Indonesia. Jakarta: Kencana.

Faisal. 2011. Restruturisasi Pembiayaan Murabahah dalam Mendukung Manajemen Risiko sebagai Implementasi Prudential Principle Pada Bank Syariah di Indonesia, Jurnal Dinamika Hukum, 11 (3), 2011.

Fatwa DSN No. 46/DSN-MUI/II-2005, Tentang potongan tagihan murabahah.

Fatwa DSN No. 49/DSN-MUI/II-2005, Tentang konversi akad murabahah.

Gandapradja, Permadi. 2004. Dasar dan Prinsip Pengawasan Bank. Jakarat: Pt. Raja Gramedia Pustaka Utama.

Harja, Rizky Maulana. 2013. Pelaksanaan Prinsip Kehatihatian dalam Perjanjian Kredit (Studi Kasus di Bank NTB), Jurnal Ilmiah Fakultas Hukum Universitas Mataram (April 2013), 4.

Ibrahim, Johannes. 2004. Cross Defeult dan Collateral Sebagai Upaya Dalam Penyelesaian Kredit Bermasalah. Bandung: PT. Refika Aditama.

Ismail. 2011. Perbankan Syariah. Jakarta: Kencana Prenada Media Group.
Karim, Adiwarman A. 2011. Bank Islam: Analisis Fiqih dan Keuangan. Jakarta: PT RajaGrafindo Persada.

Kasmir. 2007. Pemasaran Bank. Jakarta: Kencana.

Laporan Triwulan Otoritas Jasa Keuangan Tahun 2014.

Muhammad, Danang Wahyu. 2007. Penerapan Prudential Banking Pada Bank Syariah, Jurnal Media Hukum, 14(1), 2007.

Mujiyono, Agus. 2015. Penerapan Prinsip Kehati-hatian dalam Pembiayaan dan Kredit di BMT Hasanah dan BRI Unit Mlarak Ponorogo, Jurnal Muslim Heritage, Vol. 1 No. 1, 2015.

Rivai, Veithzal, dan Arviyan Arifin. 2010. Islamic Banking. Jakarta: Bumi Aksara.

Rivai, Veitzal, dan Rifki Ismail. 2013. Islamic Management for Islamic Bank. Jakarta: PT Gramedia Pustaka Utama.

Saputra, Heri. 2013. Strategi Penyelesaian Pembiayaan Bermasalah, Jurnal Publikasi UM Surakarta.

Sjedeini, St. Remy. 1993. Kebebasan Berkontrak Dan Perlindungan Yang Seimbang Bagi Para Pihak Dalam Perjanjian Kredit Bank Indonesia. Jakarta: Institute Bankir Indonesia.

Usanti, Trisadini Prasastinah. 2006. Restrukturisasi Pembiayaan sebagai Upaya Penyelamatan Pembiayaan Bermasalah, Jurnal Perspektif, Vol. XI No. 3 Tahun 2006.

Usman, Rachmadi. 2001. Aspek-aspek Hukum Perbankan di Indonesia. Jakarta: PT.Gramedia Pustaka: Utama.

Zaeni, Mia Septiana. 2010. Penerapan Prinsip Kehatihatian dan Penyelesaian Sengketa Dalam Pemberian Pembiayaan Murabahah Pada Bank Muamalat Indonesia Cabang Yogyakarta, Jurnal Penelitian Hukum Gadjah Mada, Vol. I, 2010. 